\title{
Неоад'ювантна та ад'ювантна селективна внутрішньоартеріальна регіональна хіміотерапія у хворих з раком підшлункової залози
}

\author{
М. Ю. Ничитайло, М. С. Загрійчук, В. А. Кондратюк, Ю. В. Неженцева, \\ Я. В. Романів, Т. Б. Терзова \\ Національний інститут хірургії та трансплантології імені О.О.Шалімова НАМН України, м. Київ
}

\section{Neoadjuvant and adjuvant selective intraarterial regional chemotherapy in patients with pancreatic cancer}

\author{
M. Yu. Nichitaylo, M. S. Zagriichuk, V. A. Kondratyk, Yu. V. Nezhentseva, \\ Ya. V. Romaniv, T. B. Terzova \\ Shalimov National Institute of Surgery and Transplantology, Kyiv
}

\section{Реферат}

Мета. Поділитися досвідом лікування раку підшлункової залози (ПЗ) з використанням селективної внутрішньоартеріальної регіональної хіміотерапії.

Матеріали і методи. Представлено досвід лікування пацієнтів з раком П3, яким проводили селективну внутрішньоартеріальну регіональну хіміотерапію як з метою доопераційного рестадіювання (неоад’ювантно), так і після паліативних та радикальних оперативних втручань (ад'ювантно).

Результати. Проаналізовано хірургічні аспекти лікування, зокрема, ускладнення, техніка стентування, тривалість госпіталізації, недоліки методики та перспективи ії застосування.

Ключові слова:селективна внутрішньоартеріальна регіональна хіміотерапія; рак підшлункової залози.

Abstract

Objective. To share the experience of treatment of pancreatic cancer, using selective intraarterial regional chemotherapy (SIARCH) Materials and methods. Experience of treatment was presented in patients, suffering pancreatic cancer, to whom SIARCH was conducted with the objective to do a tumor restaging - preoperatively and after performing of radical and palliative operations Results. Surgical aspects of treatment, including complications, technique of stenting, duration of stationary treatment, the procedure faults and perspective of its application.

Keywords:selective intraarterial regional chemotherapy; pancreatic cancer.

Основними факторами, які призводять до незадовільних результатів лікування раку (аденокарциноми) ПЗ, є особливості топографо-анатомічного розміщення органа, висока агресивність епітеліальних злоякісних пухлин, пізня поява клінічної симптоматики, особливо за наявності пухлин тіла та хвоста ПЗ. У порівнянні з результатами лікування злоякісних новоутворень інших органів травної системи, наприклад товстої чи прямої кишки, результати лікування раку ПЗ значно гірші, тому пошуки методик, покликаних покращити результати лікування, надзвичайно важливі та виправдані.

Низька медіана виживаності хворих з протоковою аденокарциномою та тривалість життя, яка є найнижчою серед пацієнтів з усіма відомими злоякісними пухлинами органів травної системи, свідчать про необхідність мультидисциплінарного підходу до лікування таких пацієнтів. Радикальна хірургічна операція навіть за умови виконання резекції в об'ємі R0 - це лише етап довготривалого багатовекторного лікування пацієнтів з раком ПЗ [1]. Особливо гострою є проблема лікування пацієнтів з умовно резектабельними пухлинами («borderline resectable»), оскільки локальне розповсюдження пухлини на магістральні су- дини унеможливлює резекцію, але стан пацієнта, у якого немає віддалених метастазів, канцероматозу та асциту, вважають операбельним [2, 3]. Лікування таких хворих навіть у найвідоміших світових клінічних рекомендаціях NCCN та ESMO чітко не визначено, тому пошуки шляхів максимально ефективного лікування цієї категорії хворих продовжуються [4].

Складовою комплексного лікування пацієнтів з раком П3, окрім хірургічного етапу, є різні схеми хіміотерапіі, зокрема, застосування гемцитабіну (монотерапія), гемцитабіну та 5-фторурацилу і FOLFIRINOX. Стандартний шлях введення цих препаратів фактично не забезпечує локальної дії на пухлину та метастази. Саме тому увагу спеціалістів привертає внутрішньоартеріальний таргетний селективний шлях введення хіміопрепаратів $з$ огляду на ряд його очевидних переваг. У світовій літературі опубліковані дані про локальний і системний вплив внутрішньоартеріальної селективної хіміотерапії, а можливість зменшення дози значно знижує прояви постхіміотерапевтичного інтоксикаційного синдрому [5]. Поширенню таких способів введення хіміопрепаратів перешкоджають технічні складнощі: відсутність можливості для ендоваскулярного 
встановлення порта, введення препаратів під тиском (bypump), необхідність специфічного догляду за внутрішньоартеріальним катетером, що потребує госпіталізації пацієнта до хірургічного стаціонару, тощо. Даних щодо внутрішньоартеріального введення комбінації FOLFIRINOX у лікуванні хворих з раком ПЗ ми не знайшли ані у вітчизняній, ані в зарубіжній спеціальній літературі. Даний напрямок у мультидисциплінарному підході до лікування раку ПЗ ми вважаємо перспективним і застосовуємо його в повсякденній практиці.

Мета дослідження: поділитися досвідом лікування раку ПЗ з використанням селективної внутрішньоартеріальної регіональної хіміотерапії.

\section{Матеріали і методи дослідження}

За період з вересня 2017 по лютий 2018 р. у відділенні хірургії підшлункової залози, лапароскопічної та реконструктивної хірургії жовчовивідних проток Інституту внутрішньоартеріальну селективну регіональну хіміотерапію проведено 7 пацієнтам з різними формами та стадіями раку ПЗ. У всіх спостереженнях гістологічною формою новоутворення була протокова аденокарцинома. Чоловіків було 4, жінок - 3. Пацієнти були порівнянні за віком, їх середній вік становив 57,8 року.

Хіміотерапію за схемою FOLFIRINOX (іринотекан, лейковорин, 5-фторурацил та оксаліплатин) застосовували у 2 хворих, гемцитабін у комбінації 3 5-фторурацилом у 1 хворого, монотерапію гемцитабіном - у 4 хворих. У 2 хворих діагностовано місцево-розповсюджений рак правого анатомо-хірургічного сегмента ПЗ, і як неоад'ювантний курс обидва отримали внутрішньоартеріально регіонально комбінацію FOLFIRINOX. У 1 з цих двох пацієнтів ми спостерігали рестадіювання, що дало можливість виконати радикальне оперативне втручання - панкреатодуоденальну резекцію в об'ємі R0. У іншого хворого рестадіювання не спостерігали, тому йому виконали паліативне хірургічне втручання в об’ємі гепатикоєюностомії, після чого провели повторний курс внутрішньоартеріальної терапії лише гемцитабіном. Внутрішньоартеріальна терапія проведена ад'ювантно 5 хворим: 2 - після радикальної панкреатодуоденальної резекції, 2 - після гепатикоєюностомії як способу біліарної декомпресії, 1 - після дистальної субтотальної резекції ПЗ зі спленектомією. Всім хворим виконували обов'язкову доопераційну біопсію з гістологічною верифікацією. Неоадювантна внутрішньоартеріальна хіміотерапія включала три курси: на 1-шу (день встановлення порта), 7-му та 14-ту добу (день видалення порта). Ад'ювантну внутрішньоартеріальну хіміотерапію проводили за такою самою схемою.

Пацієнту під ендоваскулярним контролем через стегнову артерію встановлювали пристрій - стент-порт безпосередньо в шлунково-дванадцятипалокишкову артерію, а після виконаної панкреатодуоденальної резекції у загальну печінкову артерію. Дистальний кінець катетера виводили та фіксували на внутрішній поверхні правого стегна. Всі пацієнти, поки стент-порт знаходився в артеріальному руслі, перебували в стаціонарі. Середня тривалість госпіталізації у разі проведення внутрішньоартеріальної хіміотерапії становила 15 діб. Стент-порт видаля- ли на 14 - 15-ту добу, відразу після останнього введення препарату. Для збереження прохідності катетер щоденно промивали фізіологічним розчином з обов'язковою гепариновою заглушкою наприкінці введення.

Неоад'ювантну хіміотерапію розпочинали відразу після гістологічної верифікації пухлини. Матеріал забирали з допомогою пункційної біопсії під контролем ендоскопічного ультразвукового дослідження (ендоУЗД). Оперативне втручання виконували через місяць після останнього введення хіміопрепаратів з обов'язковим лабораторним моніторингом. Перший курс ад'ювантного введення розпочинали через місяць після оперативного втручання з обов'язковим клінічно-лабораторним моніторингом хворого. Ефективність терапії контролювали за рівнями онкомаркерів, а також за результатами комп'ютерної томографії (КТ) органів черевної порожнини (ОЧП) з внутрішньовенним контрастуванням.

\section{Результати}

Жоден із пацієнтів, яким була проведена внутрішньоартеріальна регіональна хіміотерапія з приводу раку П3, не помер. Частота хірургічних ускладнень становила 28,5\%, однак вони не потребували оперативних втручань і були ліквідовані консервативно. Хірургічних ускладнень, які б потребували невідкладної операції, ми не спостерігали. У 5 пацієнтів розвинувся інтоксикаційний синдром I - II ступеня, у 2 - III ступеня. Серед хірургічних ускладнень у 2 хворих відмітили протікання крові навколо стент-порта в об'ємі 10 - 20 мл, що потребувало повторних перев'язок з компресійною пов'язкою. На біль в області стегна в місці виходу порта скаржився 1 пацієнт, на сильний біль в епігастрії, який зникав під впливом спазмолітиків - 1, у 1 пацієнта була гіпертермія до $39,2{ }^{\circ} \mathrm{C}$ із зворотним зривом серцевого ритму, що було розцінено як синдром масивного розпаду.

Враховуючи початковий досвід такого лікування та відсутність стандартів і алгоритмів, усім хворим внутрішньоартеріальну хіміотерапію проводили у відділенні реанімації та інтенсивної терапії для негайної корекції всіх можливих порушень. У період між введеннями препаратів хворі перебували в хірургічному відділенні загального профілю. Строки спостереження за хворими становили 3 міс. У всіх хворих прогресування захворювання не спостерігали за даними КТ та рівнем онкомаркерів.

Зокрема, у 1 хворого, якому застосовували схему FOLFIRINOX неоад'ювантно, нам вдалося виконати панкреатодуоденальну резекцію без судинної реконструкції у разі вростання пухлини у ворітну вену за даними доопераційної КТ. Однозначно стверджувати, що це стало можливо саме завдяки внутрішньоартеріальній хіміотерапії, не доводиться, але локальна дія хіміопрепарату на судинну стінку значно підвищила ефективність самого хіміотерапевтичного ефекту та з великою ймовірністю збільшила шанси на виконання радикальної операції. Тобто подальші дослідження в цьому напрямку необхідні.

Ад'ювантну внутрішньоартеріальну хіміотерапію через місяць після радикальної операції проводили з метою деструкції пухлинних клітин у гепатопанкреатодуоденальній зоні як основного джерела локорегіонального реци- 
диву та віддалених метастазів у печінку. Саме ці два явища, як правило, є ознаками прогресування та рецидиву раку ПЗ у пацієнтів після радикального хірургічного лікування. Локальних ускладнень лікування ми не спостерігали.

\section{Обговорення}

Внутрішньоартеріальне введення, попри очевидні переваги, має й численні недоліки, зокрема, невідомі віддалені результати такого лікування, оскільки доза препаратів була зменшена вдвічі у порівнянні з дозою, розрахованою для системного введення, через ймовірність тяжких ускладнень внаслідок локальної дії на кишкову стінку. 3 одного боку, забезпечується локальна дія на пухлину, а з іншого - зменшується доза препарату, а отже, системний вплив на організм. Тому подальші дослідження з метою визначення максимальної дози, яка може бути введена внутрішньоартеріально, вкрай потрібні. Оскільки існує високий ризик ускладнень введення частини препарату в артерію, а частини - системно, цей напрямок також може стати важливим для подальших наукових досліджень. До менш вагомих недоліків можна віднести відсутність клінік, де одночасно можливо забезпечити ендоваскулярну імплементацію катетера, проведення хіміотерапії та хірургічного лікування. Необхідність перебування пацієнта в стаціонарі, поки катетер знаходиться в магістральній артерії, та щоденного догляду за ним, щоб запобігти локальним ускладненням, вважають суттевими недоліками методу.

Висока ймовірність покращення загальних результатів лікування пацієнтів з раком ПЗ за допомогою внутрішньоартеріальної регіональної хіміотерапії є для нас важливим аргументом для того, щоб у дедалі більшої кількості хворих застосовувати зазначену методику, а всіх без винятку пацієнтів моніторити з метою вивчення віддалених результатів.

\section{Висновки}

1. Внутрішньоартеріальна селективна регіональна хіміотерапія у пацієнтів з раком ПЗ може бути застосована як неоад'ювантно з метою зменшення розмірів пухлини за наявності місцево-розповсюдженого раку, так і у віддаленому післяопераційному періоді з метою локальної інактивації пухлинних клітин та профілактики локорегіонального рецидиву.

2. Ускладнення, пов'язані з внутрішньоартеріальною регіональною хіміотерапією, не потребують повторних операцій та можуть бути вилікувані консервативно.

3. Дана методика безпечна та не призводить до збільшення летальності. Необхідні подальші науково-клінічні дослідження з метою іiі детального вивчення та обгрунтування ефективності й доцільності.

\section{Підтвердження \\ Фінансування}

Це дослідження є фрагментом планової НдР.

Фінансування за рахунок держбюджеу.

\section{Інформація про внесок кожного учасника}

Внесок кожного автора в цю роботу однаковий. Всі автори прочитали і схвалили остаточний варіант рукопису.

\section{Конфлікт інтересів}

Автори, які взяли участь в цьому дослідженні, декларують відсутність конфлікту інтересів щодо цього рукопису. Згода на публікацію

Всі автори дали згоду на публікацію цього рукопису.

\section{References}

1.Liu X, Yang X, Zhou G, Chen Y, Li C, Wang X. Gemcitabine-Based Regional Intra-Arterial Infusion Chemotherapy in Patients With Advanced Pancreatic Adenocarcinoma. Medicine (Baltimore).2016 Mar;95(11):e3098.https://doi.org/10.1097/MD.0000000000003098.

2.Hashimoto A, Tanaka T, Sho M, Nishiofuku H, Masada T, Sato T, et al. Adjuvant Hepatic Arterial Infusion Chemotherapy After Resection for Pancreatic Cancer Using Coaxial Catheter-Port System Compared with Conventional System. Cardiovasc InterventRadiol. 2016 Jun;39(6):8319.https://doi.org/10.1007/s00270-016-1292-7.

3.Nakayama A, Tajima H, Kitagawa H, Shoji M, Nakanuma S, Makino I, et al. A case report of hepatic arterial infusion chemotherapy and RFA for liver metastasis from pancreatic cancer. Gan To Kagaku Ryoho. 2014 Nov;41(12):2205-7.PMID:25731471.

4.Zheng YY, Tang CW, Xu YQ, Feng WM, Bao Y, Fei MY. Hepatic arterial infusion chemotherapy reduced hepatic metastases from pancreatic cancer after pancreatectomy. Hepatogastroenterology. 2014 Jul;61(133):1415-20.PMID:25436319.

5.Doi T, Homma H, Akiyama T, Mezawa S, Takahashi M, Ohi M, et al. Clinical Significance of Adjuvant Surgical Resection for Initially Unresectable Pancreatic CancerResponsive to Arterial Infusion Chemotherapy. Hepatogastroenterology. 2014 May; 61(131):828-33.PMID:26176081.

Надійшла 10.10.2018 